\title{
MIR215 wt Allele
}

National Cancer Institute

\section{Source}

National Cancer Institute. MIR215 wt Allele. NCI Thesaurus. Code C95037.

Human MIR215 wild-type allele is located in the vicinity of 1 q41 and is 110 bases in length.

This allele, which encodes MIR215 pre-miRNA, may be involved in the modulation of transcription. Aberrant expression of the gene is associated with multiple myeloma. 